\title{
Pengaruh Selfie-Liking dan Penyesuian Diri terhadap Prestasi Belajar Siswa
}

\author{
Sabrida M. Ilyas')1, Syiva Fitria ${ }^{2}$ \\ 1,2 Program Studi Bimbingan dan Konseling Islam, Institut Agama Islam Negeri (IAIN) \\ Langsa, Aceh, Indonesia. \\ *) Corresponding author, $\equiv$ e-mail: sabridailyas11@iainlangsa.ac.id
}

$\begin{array}{ccc}\text { Received: } & \text { Accepted: } & \text { Published: } \\ \text { 13 November } 2021 & \text { 13 December 2021 } & \text { 31 December 2021 }\end{array}$

\begin{abstract}
Self-liking behavior that has become a lifestyle for teenagers who are active users of social media in the technology era has the potential to cause a decrease in learning achievement which is part of the mastery of knowledge over skills from student learning outcomes. However, empirical studies that explore self-adjustment in learning for adolescents with selfie-liking behavior have not been widely studied. In this study, the researchers aimed to determine the causal relationship between selfie-liking and self-adjustment in learning with high school student achievement. Data were collected from 223 (male=29.6\%, female $=70.4 \%$ ) samples aged $16-17$ years from three public high schools in Aceh Tamiang. The instrument used in this study were selfie-liking scale and self-adjustment in learning scale. The achievement was measured by using report score.The results of the regression analysis showed that there was no significant collective effect between selfie-liking and self-adjustment in learning achievement $\left(R^{2}=0.017 ; F(2.220)=1.942 ; p=.146\right)$. Partial regression showed that individually, self-liking was not significant in predicting learning achievement $(\beta=-, 045 ; p=.529)$, while self-adjustment in learning was a significant predictor of learning achievement $(\beta=, 142 ; p=.005)$. Based on the above research, guidance and counseling teachers are expected to be able to provide preventive counseling services for the effect of excessive selfie like and provide guidance to subject teachers that although students in online learning still display selfie photos, it is not a negative impact on their mental and achievement.
\end{abstract}

Keywords: Selfie-Liking, Self-Adjusment, Achievement, Adolescents

\section{Abstrak}

Prilaku aktivitas selfie liking yang telah menjadi gaya hidup remaja pengguna aktif media social di era tehnologi berpotensi mengakibatkan penurunan prestasi belajar yang merupakan bagian dari penguasaan pengetahuan atas keterampilan dari hasil belajar siswa. Namun kajian empiris yang mengeksplorasi kemampuan penyesuian diri dalam belajar bagi remaja dengan perilaku selfie-liking yang sudah melekat belum banyak dikaji. Dalam penelitian ini, peneliti bertujuan untuk mengetahui pengaruh kausalitas antara selfie-liking dan penyesuian diri dalam belajar dengan prestasi belajar siswa SMA. Data dikumpulkan dari 223 (laki-laki= $29.6 \%$, perempuan=70.4\%) sampel yang berusia 16-17 tahun dari tiga SMA Negeri yang ada di Aceh Tamiang. Instrumen yang digunakan dalam penelitian ini adalah skala selfie-liking dan skala penyesuaian diri dalam belajar. Prestasi diukur dengan menggunakan nilai rata-rata dari rapor. Hasil analisis regresi menunjukan bahwa tidak ada pengaruh kolektif yang signifikan antara selfie-liking dan penyesuaian diri dalam belajar terhadap prestasi belajar $\left(R^{2}=0,017 ; F(2,220)=1,942 p=.146\right)$. Regresi parsial menunjukan bahwa secara individual, selfi liking tidak signifikan dalam meprediksi prestasi belajar $(\beta=-, 045 ; p=.529)$, sedangkan penyesuian diri dalam belajar merupakan prediktor yang signifikan terhadap prestasi belajar $(\beta=, 142 ; p=.05)$. Berdasarkan hasil penelitian diatas guru BK diharapkan dapat memberikan pelayanan konseling bersifat preventif akan pengaruh selfie-liking yang berlebihan dan memberikan pengarahan pada guru mapel bahwa meskipun siswa dalam pembelajaran online masih menampilkan foto selfie bukan merupakan suatu dampak negatif terhadap mental dan prestasinya.

Kata Kunci: Selfie-Liking, Penyesuian diri, Prestasi, Remaja 
This is an open access article distributed under the Creative Commons Attribution License, which permits unrestricted use, distribution, and reproduction in any medium, provided the original work is properly cited. (C2021 by author.

\section{PENDAHULUAN}

Prestasi belajar merupakan penguasaan pengetahuan atas keterampilan yang diberikan oleh guru kepada siswa atas hasil tes dengan bentuk nilai (Rosyid et al., 2019). Tinggi rendahnya pencapaian nilai prestasi belajar sangat dipengaruhi oleh factor dari internal dan eksternal diri siswa.

Salah satu factor internal yang menyebabkan rendahnya prestasi belajar siswa adalah menurunnya minat dan perhatian terhadap pelajaran akademik. Minat adalah dorongan dalam diri sendiri untuk melakukan sesuatu yang dapat membuatnya tertarik dan senang pada pembelajaran hal ini muncul karena adanya rangsangan, sedangkan perhatian adalah banyak sedikitnya kesadaran yang mengikuti aktivitas pembelajaran yang dilakukan (Firdianti, 2018).

Fenomena di era kemajuan tehnologi yang identik dengan gaya hidup digital dan kehadiran smartphone dengan fitur aplikasi canggihnya, muncul suatu kebiasaan baru remaja yaitu prilaku selfie liking yang telah mengalihkan minat dan perhatian remaja dari tugas belajarnya. Selfie adalah foto potret diri yang diambil menggunakan aplikasi kamera pada smartphone sedangkan selfie-liking terjadi ketika individu dapat merasakan adanya ikatan emosional saat melakukan selfie dan mengintegrasikannya ke dalam aktivitas sehari-hari. (Charoensukmongkol, 2016).
Laporan Asosiasi Penyelenggara Jasa Internet Indonesia dalam Ainida et al.,(2020) menyebutkan bahwa remaja merupakan pengguna internet media sosial paling banyak dan mengshare foto selfie melalui WhatsApp, Instagram, Path, Facebook dan Twitter dengan 129,2 juta pengguna sekitar 97,7\%, akibatnya waktu mereka banyak dihabiskan bersama media sosial dan tidak dapat membatasi pengunaanya . hal ini menjadikan minat dan perhatian pada pembelajaran dalam meraih prestasi menjadi berkurang.

Beberapa dampak buruk dari kebiasan menghabiskan waktu dan perhatian pada selfie liking dan mempostingnya dimedia sosial, menurut Erdem dalam Kuncoro \& Ratnamiasih (2018), mengatakan prestasi belajar dapat ditentukan dengan waktu belajar yang digunakan. Ketika remaja mengunakan smartphonenya untuk selfie liking yang berlebihan yang menyebabkan jam belajar mereka terkuras dan hal ini terdampak pada tidak selesainya tugas-tugas belajar yang diberikan guru tepat pada waktunya bahkan tidak di selesakan. Seperti obsesi seorang remaja, Junaidi Ahmad dalam bbc.com, pemilik akun Instagram dengan 50.000 pengikut, mengaku melakukan selfie sekitar 200 kali sehari, obsesinya ingin disukai banyak orang dengan menghabiskan waktu dan perhatian penuh pada selfie. Membagikan apa pun tentang 
diri ke internet inilah yang membuat remaja pelaku selfie-liking semakin popular dan membuat individu tersebut mengesampingkan apapun yang terjadi di sekitarnya termasuk tugas-tugas belajarnya karena yang terpenting adalah bagaimana agar momen tersebut tidak hilang dan terdokumentasi.

Selanjutnya fakor eksternal, yaitu lingkungan mempengaruhi prestasi belajar remaja, dalam hal ini adalah teman bergaul atau teman sebaya, merupakan lingkungan dimana remaja belajar untuk hidup bersama orang lain yang bukan anggota keluarga. Goodyear et al., (2019) mengatakan teman sebaya yang melakukan selfie dapat dianggap sebagai tekanan dari teman sebaya, ketika remaja yang memiliki harga diri yang rendah atau mengalami hal yang buruk, akan membandingkan diri mereka dengan orang lain di sekolah. Ketika melihat foto selfie dimedia sosial berpenampilan lebih baik dari pada dirinya hal ini memicu rasa depresi dan ingin mengubah penampilan yang mana akan menguras perhatian padanya sehingga akan mempengruhi perhatian pada pembelajaran di sekolah.

Hal ini di dukung oleh penelitian Ciplak (2021), menemukan perilaku selfieliking dengan berbagai gangguan kesehatan mental, seperti harga diri rendah dan gangguan persepsi terhadap tubuh sendiri. Peneliti lain menunjukkan bahwa keinginan selfie-liking yang berlebihan dikaitkan harga diri yang rendah dan kecenderungan untuk membandingkan diri mereka secara fisik dengan teman-teman sebaya mereka yang pada gilirannya terbukti menghasilkan sikap negatif terhadap penampilan sendiri (Endong, 2019).

Sedangkan menurut Juditha (2018), remaja yang suka memposting hasil selfielikingnya di media sosial berisiko membahayakan dirinya sendiri hal ini karena memposting selfie berpotensi memperburuk hubungan sosial dengan dan membuat pengunggah tidak disukai oleh orang lain dalam hal ini bisa jadi teman sebaya.

Sejauh penelusuran penulis ditemukan juga bahwa remaja pelaku selfie liking memberikan prestasi yang baik untuk sekolah dan dirinya, seperti dilaporkan Kanwil Kemenag Yogyakarta dalam rangka memperingati HUT Republik Indonesia ke76, siswa mengikuti lomba foto selfie mirip pahlawan nasional dengan tujuan kegiatan ini untuk meingkatkan cinta kepada pahlawan dan percaya diri siswa dalam berkontribusi dan membela negara seperti para pahlawan nasional (kemenag.go.id).

Penelitian yang dilakukan oleh Kircabunrun \& Griffiths (2018) yang melaporkan bahwa remaja dengan tingkat selfie-liking yang lebih tinggi merasa lebih nyaman dalam setting sosial dan ketika berkomunikasi dengan orang lain, dan menunjukkan kecemasan keterikatan yang lebih rendah terhadap persahabatan dan keterikatan kualitas yang lebih tinggi dengan teman sebaya dan orang tua. Di sisi lain, remaja dengan selfie-liking yang lebih rendah menunjukkan tingkat depresi yang lebih tinggi dan secara positif kecanduan media sosial, menjadi tidak nyaman dalam pengaturan sosial, dan mengalami masalah 
kecemasan keterikatan yang lebih tinggi dengan teman sebaya dan keluarga.

Selanjutnya Griffiths \&

Balakrishnan (2018) mengembangkan skala perilaku selfie-liking untuk mengukur tingkat keparahannya. Ditemukan ada tiga tingkat selfitis; (1) tingkat borderline (normal) adalah orang yang melakukan selfie tiga kali sehari tetapi tidak mengunggah foto ke media sosial, (2) tingkat akut, di mana foto diunggah ke media sosial, (3) tingkat kronis, di mana orang merasakan dorongan tak terkendali untuk mengambil foto narsis sepanjang waktu dan mempostingnya di media sosial lebih dari enam kali sehari. Kesimpulan penelitian ini mengungkapkan tingkat borderline (normal) tidak menganggu aktivitas maupun mentalnya sedangkan penderita selfitis (tingkat kronis memiliki kharakteristik; suka mencari perhatian, kurang percaya diri dan berharap dapat meningkatkan status sosialnya, serta merasa akan menjadi bagian dari suatu kelompok dengan menampilkan gambaran dirinya. Selanjutnya Alblooshi (2015) juga menemukan bahwa harga diri meningkat atau menurun seiring dengan peningkatan atau penurunan jumlah selfie dan berbagi.

Sisi positif lain, Tavris (2015) mengatakan selfie-liking bisa menjadi sarana gerakan sosial bagi remaja karena di era digital ini individu dituntut untuk lebih kreatif, seperti yang dilakukan penyanyi asal Amerika Serikat, Alicia Keys melakukan kampanye tanpa riasan untuk wanita yang bertujuan untuk mendorong wanita tampil cantik dengan caranya sendiri dengan hanya mengunggah beberapa foto selfie wajahnya yang tampak natural di akun Instagramnya. Lebih lanjut, penelitian selfie-liking di kalangan perempuan di grup Instagram, Purwati et al., (2016) membuktikan bahwa remaja perempuan yang tidak dianggap cantik secara sosial, mereka lebih percaya diri dengan kecantikan atau penampilan fisiknya, sehingga konsep diri mereka cenderung positif. Konsep diri yang positif dapat terlihat pada aktivitas mereka sebelum mengunggah foto selfie yaitu mereka tidak memanipulasi foto selfie mereka secara berlebihan, karena mereka dapat menerima diri mereka apa adanya, sedangkan untuk remaja putri yang sering dinilai cantik secara sosial justru memiliki lebih percaya diri rendah dan konsep diri negatif. Fenomena munculnya tren selfieliking ini dari hasil penelitian dan media sosial telah membawa pemahaman antara sisi positif dan negatif bagi remaja baik dari pembentukan prilaku, kesehatan mental maupun pencapaian prestasi.

Di sisi lain, remaja yang sedang menuju perkembangan dan perubahannya dituntut juga untuk melakukan penyesuaian diri dalam belajarnya serta mengapai prestasi belajar atau kelulusan akademik yang baik di lingkungan budaya selfie liking. Jika mereka tidak mengikuti perkembangan dan perubahan tersebut, mereka akan tersingkir dari generasi pada masanya. Penyesuaian diri merupakan suatu bentuk reaksi individu atau organisme khusus terhadap tuntutan situasi eksternal dan bagi yang tidak mampu melakukan penyesuaian diri mudah hilang, diusir dan tidak dapat melanjutkan 
keberadaannya (Rahmat, 2021). Seiring dengan perilaku selfie-liking yang telah melekat pada diri remaja yang merupakan bagian dari penyesuaian diri dengan komunitasnya, mereka juga harus mampu melakukan penyesuaian diri dalam pembelajaran dan mencapai prestasi belajar atau kelulusan. Adapun penyesuaian diri dalam pembelajaran di lingkungan sekolah menurut Arkoff (1968) dalam (Mamesah \& Kusumiati, 2019) lebih pada bagaimana kemampuan individu mencerminkan prestasi dalam melewati berbagai tuntutan di bidang akademik dan bagaimana pengaruhnya terhadap pengembangan diri dalam kemampuan. untuk mencapai kelulusan. Hal ini menjadi tantangan bagi remaja di generasi teknologi saat ini untuk dapat menyelaraskan antara perilaku selfieliking yang sudah menjadi budaya di zamannya dengan penyesuaian diri dalam ketahanan belajar untuk mencapai kelulusan yang memuaskan.

Berdasarkan hasil studi pendahuluan melalui wawancara dengan guru mata pelajaran, kesiswaan dan guru bimbingan dan konseling di tiga SMA Negeri di Kabupaten Aceh Tamiang ditemukan beberapa siswa penurunan prestasi belajar pada nilai rapornya dengan kecenderungan siswa kecanduan selfie. Potensi kecanduan terhadap selfie-liking tersebut diwujudkan dalam perilaku siswa sebagai berikut: (1) sering selfie di kelas saat jam pembelajaran masih berlangsung sehingga mengurangi fokus siswa terhadap mata pelajaran yang disampaikan oleh guru, (2) mengubah penampilan dengan menggunakan banyak aksesoris, lip balm dibibir untuk mendapatkan foto selfie yang menarik saat berfoto selfie di sekolah, (3) tidak menyelesaikan pekerjaan rumah (PR) dari guru mata pelajaran karena waktu yang dihabiskan untuk mengunggah foto di media sosial di rumah ,(4) tidak mengikuti pembelajaran online atau offline atau tidak mengikuti beberapa mata pelajaran pembelajaran yang dilakukan berulangulang, (5) ditemukan di smarthphone siswa, menyimpan dan mengunggah foto selfie ke media sosial setiap hari.

Berkaitan dengan konteks layanan bimbingan dan konseling di sekolah dimana konselor merupakan salah satu aparatur sekolah yang memiliki tanggung jawab terhadap kemajuan perkembangan belajar siswa melalui layanan bimbingan dan konseling memiliki kepentingan untuk menghindari dan menjauhkan siswa dari perilaku selfie-liking yang mengarah terhadap masalah yang mengganggu prestasi belajar dan kesehatan mental siswa. Sehingga diharapkan siswa memiliki kemampuan mengelola penggunaan smartphone dengan perilaku selfie-liking secara tepat, sehat dan bijaksana sehingga tidak mengganggu kesehatan mental tapi sebaliknya dapat meningkatkan prestasi dan kelulusan yang memuaskan.

\section{METODE}

$\begin{array}{rcr}\text { Kajian } & \text { ini } & \text { menggunakan } \\ \text { pendekatan } & \text { kuantitatif } & \text { kausalitas. }\end{array}$
Pengambilan sampel dilakukan dengan menggunakan cluster random sampling yaitu teknik pengambilan sampel berdasarkan wilayah populasi yang ditentukan oleh peneliti (Anshori \& Iswati, 2019). 
Responden merupakan siswa dari SMAN 1 Kejuruan Muda berjumlah 42 orang, SMAN 2 Kejuruan Muda berjumlah 97 orang, SMAN 2 Percontohan Karang Baru 84 orang di Aceh Tamiang. Total responden berjumlah 223 orang dengan kisaran umur 16 sampai 17 tahun terdiri dari $66(29,6 \%)$ laki-laki dan 157 (70,4\%) perempuan.

Pengumpulan data menggunakan kuesioner yang terdiri dari pertanyaan terkait data demografi dan skala selfie-liking dari Charoensukmongkol (2016) dan skala penyesuian diri dalam belajar dari Rosdiana (2009) yang telah disesuaikan dan dalam bentuk skala liker 1-5. Skala selfie-liking dengan indikator; (1) selfie membuat saya bahagia, (2) melakukan foto selfie setiap ada kesempatan, (3) mengambil foto selfie kegiatan penting dalam kehidupan, (4) dalam seminggu ada 5 - 8 kali berfoto selfie dan upload ke media sosial, (5) marah jika seseorang mencoba menghentikan berfoto selfie, sebanyak 10 item. Skala penyesuaian diri dalam belajar mencakup indikator; (1) ketahanan belajar, (2) kepercayaan diri akademik, (3) percaya diri, (4) social self, (5) locus control, (6) self-developmen, berjumlah 16 item. Sedangkan untuk prestasi belajar diukur dengan menggunakan nilai prestasi dengan mengambil nilai rata-rata rapor siswa, kemudian Instrumen dibagikan menggunakan Google Form dan dianalisis hasilnya.

Uji validitas instrumen menggunakan validitas konstruk dan uji reliabilitas menggunakan rumus alpha cronbach. Hasil validitas pada variable $\mathrm{x} 1$ dan $x 2$ menunjukan nilai significant dengan nilai $p=., 000$ dan alpha Cronbach dengan nilai variable $\mathrm{x} 1=.811$ dan variable $\mathrm{x} 2=.776$ menunjukan terdapat reliabitas tinggi. Analisis data yang digunakan dalam penelitian ini adalah analisis regresi berganda. Analisis ini digunakan karena pengukuran hubungan antar variabel melibatkan lebih dari satu variabel. Sebelum dilakukan analisis berganda terlebih dahulu dilakukan uji asumsi klasik yang terdiri dari uji normalitas, uji linieritas, uji multikolinearitas, dan uji heteroskedastisitas dengan Statistics and Services Solution 25 Version (SPSS).

\section{HASIL TEMUAN}

Berdasarkan hasil penelitian yang telah dilakukan berdasarkan hasil analisis asumsi klasik menunjukan bahwa dalam penelitian ini tidak ditemukan penyimpangan $p=0,108$; Tolerance $=0,864$; FIV $=1,157$. Hasil distribusi frekuensi variable (table 1) selfi liking siswa menunjukan hasil yang rendah dilihat dari $\mathrm{M}=27,51 ; \mathrm{DS}=6,066$. tingkat penyesuian diri dalam belajar; menunjukan tinggi dilihat dari hasil $M=62,60$; $S D=6,133$, dan tingkat prestasi belajar menunjukan tinggi dilihat dari hasil; $\mathrm{M}=83,63 ; \mathrm{SD}=4,088$.

Tabel 1

Hasil Mean, Standar Deviasion

\begin{tabular}{lrl}
\hline \multicolumn{1}{c}{ Variabel } & $M$ & \multicolumn{1}{c}{$S D$} \\
\hline Selfie-liking & 27.51 & 6.066 \\
Penyesuain Diri & 62.61 & 6.133 \\
Prestasi Belajar & 83.63 & 4.088 \\
\hline
\end{tabular}

Adapun hasil analisis regresi berganda menunjukan bahwa selfie-liking dan prestasi keduanya mampu menjelaskan 
$1.7 \%$ variasi dari prestasi $\left(R^{2}=.017 ; F(2,220)\right.$ $=1.942 ; p=.146)$. Selfie-liking tidak signifikan dalam memprediksi prestasi $(\beta=$ $-.045 ; p=.529)$ dan penyesuian diri dalam belajar mampu memprediksi prestasi $(\beta=$ ,142; $p=.05)$.

Tabel 2.

Hasil Regresi Linier Berganda

\begin{tabular}{llll}
\hline Prediktor & $b$ & $S E(b)$ & $\beta$ \\
\hline Selfie-liking & -.031 & .048 & -.045 \\
Penyesuaian & .094 & .048 & $.142^{*}$ \\
Diri & & & \\
$R^{2}$ Change & .017 & & \\
$F$ for change & 1.942 & & \\
$R^{2}$ & & & \\
${ }^{*} p=.05$ & & &
\end{tabular}

Berdasarkan temuan tersebut maka dapat diartikan bahwa selfie-liking tidak berpengaruh terhadap prestasi belajar siswa dan sebaliknya penyesuian diri dalam belajar berpengaruh terhadap prestasi belajar siswa. Selanjutnya dapat diartikan bahwa hasil penelitian menunjukkan bahwa selfie-liking dan penyesuaian diri dalam belajar secara bersama-sama atau simultan tidak memiliki pengaruh dengan variabel prestasi belajar. kemudian nilai koefisien determinasi sebesar 1,7\% memberikan informasi bahwa persentase selfie-liking berpengaruh terhadap variabel prestasi sangat kecil.

\section{PEMBAHASAN}

Dari hasil yang diperoleh menunjukkan bahwa tidak ada pengaruh positif dan signifikansi selfie-liking terhadap prestasi belajar siswa, maka dapat dikatakan bahwa pada level rendah selfieliking pada siswa tidak akan berpengaruh signifikan terhadap prestasi siswa. Hasil penelitian ini didukung oleh pendapat ( $P$. Rutledge, n.d.) bahwa perilaku selfie-liking yaitu keinginan untuk berfoto kemudian memposting dan mendapatkan "likes" dari situs jejaring sosial merupakan hal yang wajar bagi setiap orang. Keinginan ini dipengaruhi oleh perasaan karena adanya kebutuhan akan hubungan sosial.

\section{Kemudian Kerschbaum Saona} (2015) menyatakan bahwa selfie adalah evolusi alami dan tempat untuk memproyeksikan diri. karena selfie sudah menjadi cara berkomunikasi yang diterima di masyarakat saat ini, terutama bagi remaja milenial. Kemudian penelitian yang dilakukan oleh Ikhsan \& Pranata (2018) tentang motif selfie-liking di kalangan mahasiswa, dilakukan dengan pendekatan kualitatif, dengan jenis penelitian fenomenological study menemukan bahwa terdapat tiga motif selfie-liking pada mahasiswa anggota GUC yaitu; (1) Dapatkan kepuasan diri dan hiburan. (2) Membangun citra diri dan (3) menarik perhatian orang lain. Hasil penelitian ini menunjukkan bahwa pelaku selfie-liking membangun pengembangan diri yang positif.

Griffiths \& Balakrishnan (2018) menyatakan bahwa motivasi remaja dalam melakukan selfie-liking terbagi menjadi enam kategori; (1) kepercayaan diri; saat selfie, mereka merasa lebih positif berpikir tentang diri mereka sendiri, memperbaiki lingkungan; berfoto selfie di suatu tempat atau tempat khusus untuk 
mendapatkan rasa nyaman dan ingin menunjukkannya kepada orang lain, (3) kompetisi sosial; berfoto selfie untuk mendapatkan lebih banyak 'likes' di media sosial, (4) mencari perhatian; selfie untuk mencari perhatian orang lain, (5) Modifikasi mood; mengambil foto narsis untuk merasa lebih baik; (6) kesesuaian subjektif; mengambil foto narsis untuk menyesuaikan diri dengan kelompok sosial dan teman sebaya.

Hal yang sama dengan obsesi siswa untuk menunjukkan selfie-liking dengan ekspresi atau latar belakang tertentu ketika proses pembelajaran online berlangsung adalah untuk mendapatkan pengakuan diri. Bagi siswa, pengakuan ini dapat memberikan tanda dan penilaian tersendiri oleh gurunya. Selain memiliki kebutuhan diri dan perasaan yang diakui, beberapa siswa juga mendapatkan kepuasan dan kenyamanan diri saat mengunggah foto selfie yang ditampilkan, seperti ekspresi yang dianggap cantik, manis, lucu dan layak dilihat oleh publik (Setiawan \& Maring, 2020).

Menurut Rutledge (2013) bahwa selfie-liking dengan cara yang benar dapat meningkatkan kondisi psikologis seseorang. Selfie-liking dapat meningkatkan rasa percaya diri, memberikan dukungan kepada orang lain, membantu mereka melihat situasi seperti biasa, dapat menciptakan keseimbangan dan membuka pikiran jika seseorang dapat merasa lebih baik saat melakukan selfie.

Berdasarkan uraian tersebut dapat disimpulkan bahwa ketika prilaku selfie liking masih dalam katogori rendah dan sedang maka hal ini dapat menbawa kondisi psikologis yang baik bagi pelakunya, sehingga bagi remaja yang memiliki prilaku selfie liking yang normal tidak mempengaruhi prestasi belajarnya karena mereka memiliki pengakuan diri yang tinggi, meningkatkatnya percaya diri, mendapat kepuasan dan hiburan dan membangun citra diri yang positif, sehingga dapat mengembankan potensi dan secara langsung dapat meningkatkan prestasi belajar.

Selanjutnya hasil penelitian ini menunjukkan adanya pengaruh positif dan signifikansi penyesuaian diri dalam belajar dan prestasi belajar siswa menunjukkan bahwa prestasi belajar siswa di sekolah sangat ditentukan oleh penyesuaian diri dalam kemampuan bertahan dalam belajar seperti; kepedulian terhadap kegiatan belajar, kepedulian dalam mengerjakan tugas yang diberikan, keyakinan akan potensi belajar yang sama dengan orang lain, keyakinan untuk dapat terus belajar, memiliki kemampuan menjalin hubungan dengan lingkungan belajar dan orang lain, memiliki motivasi untuk berprestasi, dan memiliki sifat inisiatif. sehingga mereka mampu mengatasi konflik mental, frustrasi, kesulitan pribadi dan sosial tanpa mengembangkan perilaku menyimpang yang mengganggu tujuan belajar (Damayanti, 2015)

Dalam teori penyesuaian diri, Calhoun \& Acocella dalam (Azizah, 2019) menyatakan bahwa penyesuaian diri adalah interaksi berkelanjutan individu dengan dirinya sendiri, orang lain, dan lingkungan tempat individu itu tinggal. 
Kemudian Arkoff dalam (Vidyanindita et al., 2017) menggambarkan penyesuaian diri dalam pembelajaran di sekolah dan di perguruan tinggi yang mencerminkan seberapa mampu individu melalui semua perubahan dinamis sejalan dengan penggunaan teknologi. Selajan dengan Davidoff dalam (Sari et al., 2021) mengatakan penyesuaian dalam belajar adalah suatu proses untuk menemukan titik temu antara kondisi diri sendiri dengan tuntutan lingkungan tempat individu belajar. Adaptasi dalam pembelajaran merupakan tuntutan untuk menyesuaikan diri dengan lingkungan akademik yang dihadapi sekolah untuk memecahkan masalah saat ini dan masa yang akan datang, sehingga dapat memberikan prestasi tersendiri.

Penelitian yang telah dilakukan oleh Hidayati Farid (2016) menemukan bahwa teman sebaya memiliki pengaruh yang besar terhadap lingkungan perilaku belajar seorang remaja. Ditemukan bahwa masih banyak remaja yang menggunakan standar peer study group untuk membantu mereka mencapai prestasi yang baik. Pengaruh peer learning group inilah yang membuat siswa berusaha terobsesi dan mampu bertahan untuk menandingi kelompoknya dalam mencapai prestasi dan menyelesaikan pendidikannya. Pengaruh peer group ini juga menjadi sebab remaja melakukan selfie karena supaya dapat diterima dilingkungan teman sebayanya, ketika mereka dapat diterima maka remaja mendapatkan kebahagian dan motivasi belajar dalam hal apa saja.
Dari pembahasan diatas dapat disimpulkan bahwa perilaku selfie-liking saat ini sudah menjadi hal yang lumrah dan sudah menjadi budaya dalam masyarakat modern sehingga setiap individu khususnya remaja saat ini, dengan setiap aktivitas yang dilakukan seolah-olah ada yang hilang jika selfie tidak hadir dalam setiap kegiatan. Kemudian ketika remaja menyukai selfie liking masih dalam taraf rendah dan sedang serta masih terkontrol dapat memberikan efek positif bagi remaja dalam perkembangannya dan tidak mengganggu prestasi akademik. Sehingga dapat diartikan bahwa jika tingkat kesukaan selfie-liking pada siswa rendah maka kecenderungan untuk berprestasi semakin tinggi. Sebaliknya jika kesukaan selfie siswa tinggi maka kecenderungan untuk berprestasi semakin rendah. Selanjutnya jika remaja mampu beradaptasi dengan perkembangan zamannya, mahir dalam penggunaan teknologi dan matang dalam menyesuaikan diri antara gaya hidup selfie-liking dan ketahanan dalam belajar dalam meningkatkan prestasi belajar, maka tren selfie-liking dapat dimanipulasi menjadi sarana meningkatkan prestasi belajar dengan bantuan guru-guru di sekolah.

\section{SIMPULAN}

Berdasarkan hasil kajian ditemukan bahwa tidak ada pengaruh yang signifikan antara selfie-liking dan penyesuaian diri dalam pembelajaran dengan prestasi belajar siswa SMA Negeri di Aceh Tamiang. Sehingga semakin rendah kesukaan selfieliking siswa dan diimbangi dengan tinggi 
penyesuaian diri dalam belajar maka semakin tinggi pula tingkat prestasi belajar siswa. Berdasarkan hasil kajian tersebut Guru BK/Konselor sekolah diharapkan dapat memberikan pelayanan konseling bersifat preventif akan bahaya selfie-liking yang berlebihan dan bekerjasama dengan guru mata pelajaran dan wali kelas tentang budaya selfie yang dapat dimanipulasi sebagai sarana untuk meningkatkan percaya diri, motivasi siswa dalam pembelajaran. Selanjutnya meskipun siswa dalam pembelajaran online masih menampilkan foto selfie bukan berarti merupakan suatu dampak hal yang negatif terhadap mental dan prestasinya.

\section{UCAPAN TERIMA KASIH}

Terima kasih kepada Kepala Sekolah, Bidang Kesiswaan, Wali kelas dan Guru BK dan siswa SMA Negeri 1 Kejuruan Muda, SMA Negeri 2 Kejuruan Muda dan SMA Negeri 2 Percontohan Karang Baru di Aceh Taming yang telah memberikan izin serta menjadi responden dalam proses penelitian ini, semoga Allah selalu melimpahkan keberkahan dan rahmat-Nya atas bantuan dan kerjasama yang telah diberikan.

\section{DAFTAR PUSTAKA}

Ainida, H. F., Lestari, D. R., \& Rizany, I. (2020). Hubungan penggunaan media sosial dengan kualitas tidur remaja di Madrasah Aliyah NegeriI 4 Banjar. CNJ: Caring Nursing Journal, 4(2), 4753.

Alblooshi, A. (2015). Self-esteem levels $\mathcal{E}$ selfies: The relationship between self- esteem levels and the number of selfies people take and post, and the uses and gratifications of taking and posting selfies. Middle Tennessee State University.

Anshori, M., \& Iswati, S. (2019). Metodologi penelitian kuantitatif: edisi 1. Airlangga University Press.

Azizah, A. (2019). Efektivitas layanan bimbingan kelompok teknik diskusi untuk meningkatkan penyesuaian diri di sekolah pada Siswa Kelas VII SMP N 3 Majenang Tahun Ajaran 2019/2020. Universitas Ahmad Dahlan.

Bela Shah (2018, Februari). Junaid Ahmed si raja selfie: Kecanduan swafoto hingga 200 kali sehari. Retrieved October 15,2021 , from https://www.bbc.com/indonesia/maja lah-43297431

Charoensukmongkol, P. (2016). Exploring personal characteristics associated with selfie-liking. Cyberpsychology, 10(2). https://doi.org/10.5817/CP20162-7

Ciplak, E. (2021). The selfitis behavior scale: An adaptation study. European Journal of Educational Sciences, 8(2), 29-41.

Damayanti, E. (2015). Peran belajar berdasar regulasi diri dan penyesuaian diri terhadap prestasi belajar siswi Madrasah Tsanawiyah Muallimat Yogyakarta. Jurnal Biotek, 3(2), 54-69.

Doğan, U., \& Adigüzel, A. (2017). Effect of selfie, social network sites usage, number of photos shared on social network sites on happiness among University Students: A Model Testing. Journal of Education and Practice, 8(27), 1735-2222. 
Endong, F. P. C. (2019). Selfie-objectification as a facet of the social media craze among youths in Nigeria: A sociocultural discourse. In Internet and Technology Addiction: Breakthroughs in Research and Practice (pp. 285-301). IGI Global.

Fischetti, M., \& Turkle, S. (2014). The networked primate. Scientific American, 311(3), 82-85.

Firdianti, A. (2018). Implementasi manajemen berbasis sekolah dalam meningkatkan prestasi belajar siswa. Gre Publishing.

Goodyear, V. A., Armour, K. M., \& Wood, H. (2019). Young people and their engagement with health-related social media: New perspectives. Sport, Education and Society, 24(7), 673-688.

Griffiths, M. D., \& Balakrishnan, J. (2018). The psychosocial impact of excessive selfie-taking in youth: A brief overview. Education and Health, 36(1), 3-6.

Hidayati, K. B., \& Farid, M. (2016). Konsep diri, adversity quotient dan penyesuaian diri pada remaja. Persona: Jurnal Psikologi Indonesia, 5(02).

Ikhsan, R., \& Pranata, L. (2018). Motif Selfie di Kalangan Mahasiswa: Studi Fenomenologi pada Grup Instagram UNP Cantik. Jurnal Sosioglobal: Jurnal Pemikiran Dan Penelitian Sosiologi, 2(2). Juditha, C. (2018). Presentasi Diri Dalam Media Sosial Path. Jurnal PIKOM (Penelitian Komunikasi Dan Pembangunan), 15(1), 17-32.

Kerschbaum Saona, R. M. (2015). Selfie El fenómeno que trasciende la web. Quito, 2015.
Kircaburun, K., \& Griffiths, M. D. (2018). Instagram addiction and the Big Five of personality: The mediating role of self-liking. Journal of Behavioral Addictions, 7(1), 158-170.

Lisnawati, Y. (2014, August 25). Tragis, Remaja ini Jatuh dari Ketinggian karena ingin Selfie. Retrieved Oktober 17,2021, from https://www.google.com/amp/s/m.lip utan6.com/amp/2095741/tragisremajaini-jatuh-dari-ketinggiankarena-ingin-selfie.

Mamesah, T. S., \& Kusumiati, R. Y. E. (2019). Hubungan Antara Efikasi Diri Akademik dengan Penyesuaian Diri Pada Mahasiswa Baru Provinsi NTT yang Merantau di Universitas Kristen Satya Wacana Salatiga. Psikologi Konseling, 14(1).

Purwati, P., Santosa, H. P., Rahmiaji, L. R., \& Ayun, P. Q. (2016). Fenomena selfie kalangan remaja perempuan di instagram. Interaksi Online, 4(1).

Rosdiana, Dewi. (2009). Penyusunan modul pelatihan penyesuian akademik bagi mahasiswa UNISBA tingkat pertama. Diakses pada tanggal 9 November 2021.

https://ejournal.unisba.ac.id/index.ph p/schema/article/view/2618/1712

Rosyid, M. Z., Mansyur, M., IP, S., \& Abdullah, A. R. (2019). Prestasi belajar. Literasi Nusantara.

Rutledge, P. B. (2013). The psychology of mobile technologies. Global Mobile: Applications and Innovations for the Worldwide Mobile Ecosystem, 47-52. 
Sari, D. O., Drupadi, R., \& Syafrudin, U. (2021). Peran orang tua dalam proses penyesuaian diri anak usia dini terhadap kegiatan pembelajaran di rumah. Pedagogi: Jurnal Anak Usia Dini Dan Pendidikan Anak Usia Dini, 7(2), 149-160.

Setiawan, R., \& Maring, P. (2020). Motif berfoto selfie untuk presensi kehadiran kelas online saat pandemi Covid-19 di Kalangan Pelajar Sekolah Dasar. Jurnal Pewarta Indonesia, 2(2), 90-96.

Tavris, C. (2015). The gadfly: photographer's amnesia, or the side effects of selfies. Skeptic (Altadena, CA), 20(4), 6-8.

https:/diy.kemenag.go.id/16615-lombaselfie-unik-ala-mtsn-1-bantul.html, September 2021. 